\title{
7th International Symposium on Particle Toxicity
}

\author{
Maastricht, The Netherlands, October 13-15, 1999
}

\section{John Hoskins}

Reigate, UK

This, the latest in a series of symposia convened about every 4 years or so maintained the popularity of its predecessors. The opening talk by Prof. Ken Donaldson from Edinburgh gave a reprise of the past meetings broken down into subject and interest shown as measured by publications. Far from being a self-congratulatory spacefiller this very learned talk demonstrated how ideas have changed over the years and how we have seen the rise and fall of a number of theories, but it stopped short of crystal ball gazing. We may think we can see the road ahead, but history has taught us that the future is not predictable. Genetics and DNA analysis will feature strongly, but we must wait to see the ends to which they will be used.

One of the major concerns in particle toxicity today is the putative role of fine and ultra-fine atmospheric particles in causing morbidity and death. I use the word putative because there is no universal acceptance that such a dramatic response to exposure to low levels of air pollutants can occur. Cardiac dysfunction in high-risk populations of those with pre-existing cardiopulmonary disease is still being assessed by the epidemiologists. However, there is a lot of evidence that small particles, probably those below $1 \mu \mathrm{m}$ in size, do have an effect. A major problem in any studies of the subject is in translating something as ill-defined and dynamic as air pollution into the laboratory. Moreover, since air pollution is invariably a complex mixture, the problem becomes increasingly difficult. Toxicology has largely been concerned with single agents so there is little supporting background and for the future the opportunities for studying mixtures are considerable. However, what to study is not an easy question to answer. Do particles alone have an effect or do they act with other pollutants? If we look at other compounds, then the role of ozone in particular is of interest since this has a profound effect on all life forms at levels little more than we experience in our cities when the sun shines. The toxicology of mixtures is in its infancy, but this meeting showed it is set to become a growth area of research.

The other major topic in particle toxicity concerns the fibrogenicity and carcinogenicity of fibrous particles in the lung. The role of reactive oxygen species, or whether iron and Fenton chemistry are causing the effects, is still fiercely debated. As the inflammation process is ever more finely dissected, more genes and their products come into the arena. Since the causative agent is well characterised compared to those in particulate air pollution toxicity, laboratory work can better aid an understanding of the human diseases. The epidemiologists have concluded a lot of work on fibre toxicity and it is now down to laboratory studies to produce a good scheme of biological plausibility. The theories of yesteryear in which fibres were thought to enter the cell and then the nucleus causing disruption of spindle formation and consequent genetic damage have gone. The main thrust of work today concerns inappropriate genetic response to 'artificial' stimuli produced by fibres interacting with the cell sur-

\section{KARGER}

Fax +41613061234

E-Mail karger@karger.ch www. karger.com (c) 2000 S. Karger AG, Basel

Accessible online at: www. karger.com/journals/ibe 
face. The pace of the studies, as with all DNA research, is dazzling and it is this more than anything else which makes it unwise to try and predict the future.

The meeting held its audience to the extent that an evening session in the form of a debate was as well attended as the other sessions. Two motions were proposed; the first on whether quartz is a proven carcinogen in humans was lost although the case was well argued. The problem seems to be that the epidemiology is not as clear-cut as, say, for asbestos, and laboratory models are also less convincing. I felt that the motion was lost reluctantly and not by many votes. The second motion on whether in vitro dissolution is able to predict carcinogenicity of fibres was won to the relief of the mineral fibre industry. Again the vote was not overwhelming and one felt that in both debates the commercial and financial implications of what was being discussed affected the way in which people responded regardless of the oratory. 